\title{
Effect of ikaite precipitation on phosphate removal in sea ice
}

\author{
Yu-Bin $\mathrm{Hu}^{1}$ \& Feiyue Wang ${ }^{2}$ \\ 'Institute of Marine Science and Technology, Shandong University, Qingdao, Shandong, China; \\ ${ }^{2}$ Centre for Earth Observation Science, and Department of Environment and Geography, University of Manitoba, Winnipeg, Manitoba, Canada
}

\begin{abstract}
Ikaite $\left(\mathrm{CaCO}_{3} \cdot 6 \mathrm{H}_{2} \mathrm{O}\right)$ precipitation in sea ice has been shown to affect $\mathrm{CO}_{2}$ exchange between the atmosphere and ocean. A laboratory study indicates that it could also co-precipitate phosphate from sea ice, which has the potential to affect sea-ice biogeochemical processes. However, the relative importance of ikaite precipitation on phosphate removal under sea-ice conditions remains unknown. We investigated ikaite precipitation in both frost flowers and seaice (under two scenarios: flooded by seawater and non-flooded) in an outdoor sea-ice mesocosm experiment, and in sea ice under natural conditions in north-eastern Greenland. The ice mesocosm experiment showed that ikaite was highly enriched in frost flowers with a concentration of up to $350 \mu \mathrm{mol} \cdot \mathrm{kg}^{-1}$. Ikaite was also detected in the surface layer of sea ice, ranging from ca. $13 \mu \mathrm{mol} \cdot \mathrm{kg}^{-1}$ in the non-flooded ice to ca. $95 \mu \mathrm{mol} \cdot \mathrm{kg}^{-1}$ in the flooded ice. However, under all these conditions, no phosphate co-precipitation with ikaite was observed. The field study in Greenland showed similar results: ikaite was detected in surface ice with an average concentration of $13.8 \mu \mathrm{mol} \cdot \mathrm{kg}^{-1}$, but no phosphate removal due to ikaite precipitation was observed. These results suggest that the impact of ikaite precipitation on phosphate and the sea-ice ecosystem might not be as significant as imagined previously.
\end{abstract}

Keywords

Co-precipitation; surface ice; frost flowers; Greenland

\section{Correspondence}

Yu-Bin Hu, Institute of Marine Science and Technology, Shandong University, Qingdao, Shandong 266237, China.

E-mail: yubinhu@sdu.edu.cn

\section{Abbreviations}

SERF: Sea-ice Environmental Research Facility, University of Manitoba in Winnipeg, $\mathrm{MB}$, Canada

TA: total alkalinity

\section{Introduction}

Sea ice is an important interface between the ocean and the atmosphere, influencing the fluxes of many climate-relevant substances. It acts as a source or sink of organic matter, nutrients and gases in micro-scale environments (Loose et al. 2011). Sea ice is also an important habitat for ice algae and microorganisms, including bacteria and viruses (Deming \& Collins 2017). The freeze-rejection process during sea-ice formation can cause concentrations of nutrients such as phosphate to be highly enriched in brine pockets and channels (Gleitz et al. 1995). High concentrations of phosphate were also reported in association with organic-rich sediment layers in sea ice, indicating contribution from the remineralization of particulate matter (Nomura et al. 2010). Fripiat et al. (2017) compiled data of nutrients in Antarctic sea ice and showed that salinity-normalized phosphate was accumulated in sea ice in spring-summer and depleted, relative to seawater, in winter in the interior and the top layer of sea ice; this seasonal difference is hypothesized to be caused by a preferential remineralization of phosphate, and/or retention in sea ice via phosphate adsorption onto metal-organic complexes, which requires further studies.

Ikaite $\left(\mathrm{CaCO}_{3} \cdot 6 \mathrm{H}_{2} \mathrm{O}\right)$ precipitation has been found in both Antarctic and Arctic sea ice (Dieckmann et al. 2008; Dieckmann et al. 2010). A laboratory-based study (Hu et al. 2014) revealed that phosphate could be strongly co-precipitated with ikaite; depending on experimental conditions, about $42-97 \%$ of the phosphate was removed from the solutions because of ikaite precipitation. If these laboratory-based results hold true under natural sea-ice conditions, phosphate could be preserved in ikaite during wintertime, and released again when ikaite dissolves (at the same time as the ice melts), which could boost biological activity in the underlying seawater in next spring. However, no field studies have ever examined this possibility.

The objective of this study was to investigate the effect of ikaite precipitation on phosphate removal in sea ice under mesocosm and field conditions. In order to obtain enough ikaite samples for this study, only the ice from the surface layer as well as frost flowers, where ikaite is 
highly concentrated, was investigated to test the hypotheses proposed by Hu et al. (2014) that ikaite precipitation removes phosphate in sea ice.

\section{Methods}

\section{Ice mesocosm experiment}

A sea-ice growth experiment was carried out at SERF in January-February 2015. The $18.3 \mathrm{~m}$ (length) $\times 9.1 \mathrm{~m}$ (width) $\times 2.6 \mathrm{~m}$ (depth) in-ground tank has an operational seawater volume of $380 \mathrm{~m}^{3}$. Artificial seawater at a salinity of 32.2 was prepared according to the methods of Millero (2006) by dissolving various commercially available salts into groundwater (Hare et al. 2013). In addition, 100 -g $\mathrm{K}_{2} \mathrm{HPO}_{4}$ was added to the tank to a final phosphate concentration of $1.60 \mu \mathrm{mol} \cdot \mathrm{kg}^{-1}$. During the ice-growth experiment, the tank was covered by a retractable roof to prevent accumulation of snow on sea ice (Fig. la).

The frost flower experiment was carried out first: when ice grew to a few centimetres, seawater from below was sprayed onto a certain sea-ice area, creating a small ice-free zone and oversaturation of water vapour over the rest of ice surface to promote formation of frost flowers (Galley et al. 2015). This resulted in a massive frost flower blossom on the surface of sea ice (Fig. 1b). Duplicate frost flower samples with an average mass of around $170 \mathrm{~g}$ were collected in Whirl-Pak bags.

At the end of the frost flower experiment, the sea ice together with frost flowers was completely melted by heating up the seawater from the bottom of the pool. Once the tank became ice free, the heater was switched off and sea ice grew under calm conditions for over one month until the ice thickness reached around $40 \mathrm{~cm}$. On 31 st day, the surface ice (ca. 0-1 cm) was scratched by a clean metal blade and collected in a Whirl-Pak bag. Duplicate samples with an average mass of around 260 $\mathrm{g}$ at two different locations were collected; these samples are referred to as "surface ice." In addition, we simulated sea ice being flooded by seawater by pouring seawater onto old ice surface within a $1.2 \mathrm{~m} \times 1.2 \mathrm{~m}$ area blocked by Styrofoam to form highly saline new ice with a thickness of around $1 \mathrm{~cm}$ (Fig. 1c). Triplicate samples with an average mass of around $380 \mathrm{~g}$ were collected after 10 days of the new ice-growth experiment; these samples are referred to as "new ice."

\section{Field sampling in Greenland}

A field campaign near the Villum Research Station, Station Nord $\left(81^{\circ} 36^{\prime} \mathrm{N}, 16^{\circ} 40^{\prime} \mathrm{W}\right)$, north-eastern Greenland, was carried out in April 2015. The ambient air temperature was as low as $-20{ }^{\circ} \mathrm{C}$. Sea ice was covered by thick snow (ca. $1 \mathrm{~m})$, resulting in a sea-ice freeboard of about $-20 \mathrm{~cm}$. After the snowcover was removed, surface ice samples with an average mass of around $280 \mathrm{~g}$ were collected from the ice surface $(<1 \mathrm{~cm}$ in thickness) at two locations that were about $3 \mathrm{~km}$ apart.

\section{Sea-ice temperature and salinity measurements}

The temperature of ice samples (including frost flowers) was measured in situ by a hand-held digital thermometer probe (Traceable ${ }^{\circledR}$ model 4000, Control Company) with a precision of $0.1{ }^{\circ} \mathrm{C}$. The bulk salinity of the meltwater samples was measured by a conductivity meter (Orion Star A212, Thermo Scientific) at room temperature with a precision of 0.1. Brine salinity was calculated from the measured sea-ice temperature according to Cox \& Weeks (1983).

\section{Ikaite and phosphate quantification}

After ice samples were collected, they were weighed (as $m_{0}$ ) and melted in a fridge where the temperatures did not exceed $4{ }^{\circ} \mathrm{C}$ to minimize the dissolution of ikaite (Dieckmann et al. 2008). Once the ice was melted completely but before ikaite crystals had started to dissolve (Rysgaard et al. 2012), the upper portion of the meltwater was quickly filtered through a 0.22 - $\mu \mathrm{m}$ Millipore filter
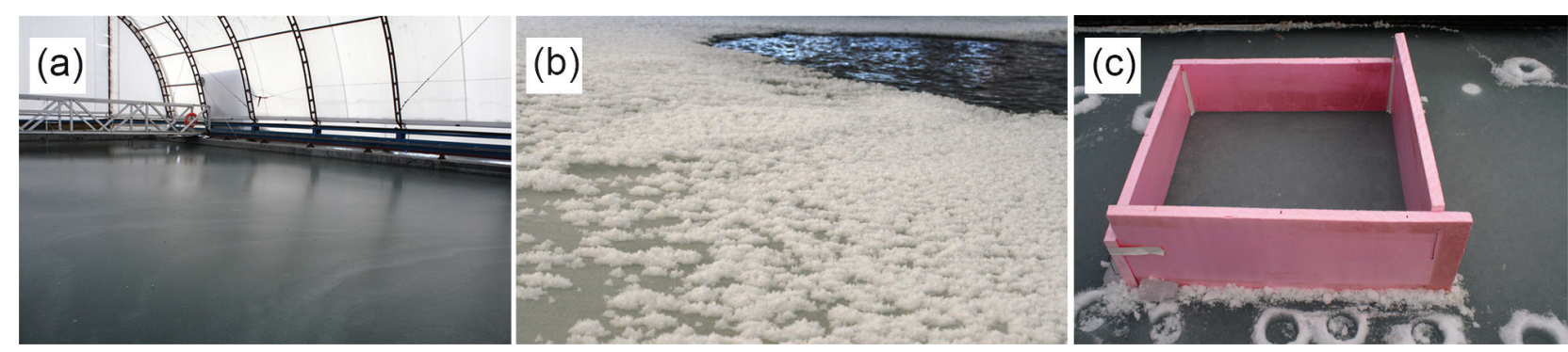

Fig. 1 (a) The sea ice mesocosm experiment in the SERF outdoor pool; (b) massive frost flowers growing on ice surface; and (c) new ice growing on old ice surface inside an area isolated by Styrofoam. 
(mixed cellulose esters membrane) using a glass syringe. The filtered water was used for TA and phosphate measurements, denoted as $\mathrm{TA}_{0}$ and $\left(\mathrm{PO}_{4}\right)_{0}$. The remaining meltwater was weighed (as $m^{\prime}$ ) again and slowly brought to room temperature in dark for at least two hours to ensure that ikaite crystals were completely dissolved, but not more than for 12 hours to minimize the impact of biological activity. Then the remaining meltwater was also filtered and used for final TA and phosphate measurements, denoted as $\mathrm{TA}^{\prime}$ and $\mathrm{PO}_{4}{ }^{\prime}$. TA was measured using a TIM 840 titration system (Radiometer Analytical, ATS Scientific Inc.) with a precision of better than $\pm 3 \mu \mathrm{mol} \cdot \mathrm{kg}^{-1}$. Phosphate measurements were done by using UV-Vis spectroscopy (Cary 5000) at a wavelength of $880 \mathrm{~nm}$ according to Murphy \& Riley (1962), with a precision of better than $\pm 0.02 \mu \mathrm{mol} \cdot \mathrm{kg}^{-1}$.

The dissolution of ikaite in meltwater is described by

$$
\mathrm{CaCO}_{3} \cdot 6 \mathrm{H}_{2} \mathrm{O}+\mathrm{CO}_{2} \leftrightarrow \mathrm{Ca}^{2+}+2 \mathrm{HCO}_{3}^{-}+5 \mathrm{H}_{2} \mathrm{O}
$$

Since $1 \mathrm{~mol}$ of ikaite dissolution will result in $2 \mathrm{~mol}$ TA increase according to Eqn. 1, the amount of ikaite ( $\Delta$ ikaite) in the ice samples can bequantified from the difference between the alkalinity of meltwater after and before ikaite dissolution:

$$
\Delta \text { ikaite }=\frac{1}{2}\left(\mathrm{TA}^{\prime}-\mathrm{TA}_{0}\right) \times m^{\prime} / m_{0}
$$

The amount of phosphate removed by ikaite precipitation $\left(\Delta \mathrm{PO}_{4}\right)$ was quantified from the difference between the phosphate of meltwater after and before ikaite dissolution:

$$
\Delta \mathrm{PO}_{4}=\left(\mathrm{PO}_{4}^{\prime}-\left(\mathrm{PO}_{4}\right)_{0}\right) \times m^{\prime} / m_{0}
$$

\section{Results and discussion}

In the ice mesocosm experiment, as shown in Table 1, the average bulk salinity of frost flowers was 44.8, followed by that of new ice as 35.1 and surface ice as 13.2. The temperatures and brine salinities of frost flowers, new ice and surface ice were $-14{ }^{\circ} \mathrm{C}$ and $171.5,-9.2{ }^{\circ} \mathrm{C}$ and 136.3 and $-10{ }^{\circ} \mathrm{C}$ and 142.8 , respectively, which are comparable with the natural conditions reported by Geilfus et al. (2013). The ikaite concentrations in frost flowers were $353.5 \pm 8.3 \mu \mathrm{mol} \cdot \mathrm{kg}^{-1}$ (average \pm standard deviation), $94.4 \pm 14.2 \mu \mathrm{mol} \cdot \mathrm{kg}^{-1}$ for new ice and $12.7 \pm$ $2.5 \mu \mathrm{mol} \cdot \mathrm{kg}^{-1}$ for surface ice. Surface ice samples collected in north-eastern Greenland had an average bulk salinity of 10.6 , relatively warm temperature of $-4.4{ }^{\circ} \mathrm{C}$ and low brine salinity of 76.4 due to the thermo-isolation provided by snow cover. The average ikaite concentration of $13.8 \pm 12.1 \mu \mathrm{mol} \cdot \mathrm{kg}^{-1}$ is in the same range as found in the ice mesocosm experiment for the surface ice and other published studies (e.g., Fischer et al. 2013; Geilfus et al. 2013). For all the surface ice and new ice samples in the ice mesocosm experiment as well as the surface ice samples from the field, the concentrations of phosphate measured before and after ikaite dissolution showed no difference for all the ice samples within the analytical uncertainty (Table 1). For instance, the phosphate concentration in the new ice sample was $1.89 \pm 0.02 \mu \mathrm{mol} \cdot \mathrm{kg}^{-1}$ before ikaite dissolution and $1.88 \pm 0.02 \mu \mathrm{mol} \cdot \mathrm{kg}^{-1}$ after ikaite dissolution. Higher phosphate concentrations were observed in frost flower samples as expected, but with a slight decrease after ikaite dissolution; on average, the phosphate concentration decreased from 2.65 to 2.49 $\mu \mathrm{mol} \cdot \mathrm{kg}^{-1}$. The reason for decrease in phosphate concentration is not clear in this study. However, it could be due

Table 1 Temperature (T), salinity (S) and the amount of ikaite precipitated in frost flowers, surface ice and new ice grown at Sea-ice Environmental

\begin{tabular}{|c|c|c|c|c|c|c|c|c|c|}
\hline Ice sample & & & $\mathrm{T}\left({ }^{\circ} \mathrm{C}\right)$ & Bulk S & Brine S & $\begin{array}{c}\text { Ikaite } \\
\left(\mu \mathrm{mol} \cdot \mathrm{kg}^{-1}\right)\end{array}$ & $\begin{array}{c}\left(\mathrm{PO}_{4}\right)_{0} \\
\left(\mu \mathrm{mol} \cdot \mathrm{kg}^{-1}\right)\end{array}$ & $\begin{array}{c}\mathrm{PO}_{4}^{\prime} \\
\left(\mu \mathrm{mol} \cdot \mathrm{kg}^{-1}\right)\end{array}$ & $\begin{array}{c}\Delta \mathrm{PO}_{4}^{\mathrm{a}} \\
\left(\mu \mathrm{mol} \cdot \mathrm{kg}^{-1}\right)\end{array}$ \\
\hline \multirow{7}{*}{ SERF } & \multirow{2}{*}{ Frost flower } & 1 & \multirow{2}{*}{-14} & 41.7 & \multirow{2}{*}{171.5} & 347.6 & 2.51 & 2.33 & -0.18 \\
\hline & & 2 & & 47.8 & & 359.4 & 2.79 & 2.65 & -0.14 \\
\hline & \multirow{2}{*}{ Surface ice } & 1 & \multirow{2}{*}{-10} & 12.0 & \multirow{2}{*}{142.8} & 14.5 & 0.27 & 0.25 & -0.02 \\
\hline & & 2 & & 14.4 & & 10.9 & 0.66 & 0.66 & 0 \\
\hline & \multirow{3}{*}{ New ice } & 1 & \multirow{3}{*}{-9.2} & 34.6 & \multirow{3}{*}{136.3} & 98.2 & 1.91 & 1.91 & 0 \\
\hline & & 2 & & 35.0 & & 84.3 & 1.87 & 1.87 & 0 \\
\hline & & 3 & & 35.9 & & 104.4 & 1.89 & 1.87 & 0.02 \\
\hline \multirow{2}{*}{ Greenland } & \multirow{2}{*}{ Surface ice } & 1 & \multirow{2}{*}{-4.4} & 12.1 & \multirow{2}{*}{76.4} & 22.4 & 0.25 & 0.26 & 0.01 \\
\hline & & 2 & & 9.2 & & 5.3 & 0.23 & 0.23 & 0.00 \\
\hline
\end{tabular}
Research Facility (SERF) as well as in surface ice from north-eastern Greenland. Also shown are the phosphate $\left(\mathrm{PO}_{4}\right)$ concentrations before and after ikaite dissolution and their difference $\left(\triangle \mathrm{PO}_{4}\right)$.

a Here, $\Delta \mathrm{PO}_{4}=\left(\mathrm{PO}_{4}{ }^{\prime}-\left(\mathrm{PO}_{4}\right)_{0}\right.$. Phosphate concentration within $\pm 0.02 \mu \mathrm{mol} \cdot \mathrm{kg}^{-1}$ is considered to be 0 because of uncertainty in instrumental analysis. 
to biological uptake during sample processing. In other words, phosphate removal was neither detected by ikaite precipitation under any of the experimental conditions in the ice mesocosm experiment nor in the natural sea ice in this study, which is in contrast with the laboratory-based results obtained by Hu et al. (2014).

It is noted in this study that the amount of ikaite precipitated was rather small, even in the frost flower samples, where the concentration of ikaite was about 353.5 $\mu \mathrm{mol} \cdot \mathrm{kg}^{-1}$. In comparison, in the study done by $\mathrm{Hu}$ et al. (2014), the final ikaite concentrations ranged from 4800 to $8646 \mu \mathrm{mol} \cdot \mathrm{kg}^{-1}$, which is about one to two order of magnitude larger than those detected in this study. Is this the reason why no phosphate removal was observed in this study? As revealed by $\mathrm{Hu}$ et al. (2014), phosphate removal due to ikaite precipitation mainly occurred at the ikaite nucleation stage (i.e., the amount of ikaite at this stage is very small); further growth of ikaite crystals did not have a significant impact on phosphate removal, suggesting that phosphate removal is not related to the total amount of ikaite precipitated. Therefore, the difference between the total amount of ikaite precipitated in the laboratory-based experiment and the ice mesocosm experiment is insufficient to explain the difference in phosphate removal. The results obtained by Hu et al. (2014) further indicate that a larger amount of phosphate was co-precipitated with ikaite at higher solution ikaite saturation level. For instance, in the study done by $\mathrm{Hu}$ et al. (2014), the percentage of phosphate removal increased from 42 to $97 \%$ as the solution saturation level with respect to ikaite increased from 3.02 to 5.37 . Therefore, the fact that no or negligible phosphate was removed by ikaite precipitation in the sea-ice mesocosm experiment as well as in the field investigation would suggest that ikaite might have precipitated at a rather low solution saturation level in sea ice. Under laboratory conditions, the precipitation of ikaite can occur very rapidly, within hours to minutes; however, it may take days or weeks for ikaite to precipitate in natural sea ice (Papadimitriou et al. 2014). The nucleation rate of ikaite in sea ice and even in frost flowers might be too slow to cause any significant removal of phosphate. The role of ikaite precipitation in phosphate concentration therefore appears to be insignificant.

\section{Conclusion}

Ikaite precipitation in sea ice was observed in both the sea-ice mesocosm experiment and the field study in north-eastern Greenland. However, no phosphate removal due to ikaite co-precipitation was detected. This indicates that ikaite precipitation in ice mesocosm experiment and at field site occurred at low-solution ikaite saturation level and that its precipitation does not remove a significant amount of phosphate from sea ice. The impact of ikaite precipitation on phosphate removal in sea ice and thereby on biological activity might not be as significant as imagined previously.

\section{Acknowledgements}

We thank David Binne for his help during the SERF experiment, and the Arctic Science Partnership and the Villum Research Station for their logistical support for field campaign at Station Nord, Greenland. Three anonymous reviewers provided helpful and constructive comments that improved the manuscript substantially.

\section{Funding}

This work was financially supported by the National Natural Science Foundation of China (grant no. 41806094), Young Scholars Program of Shandong University (grant no. 2018WLJH43), Fundamental Research Funds of Shandong University (grant no. 2017TB005), the Natural Sciences and Engineering Research Council of Canada and the Canada Research Chairs programme.

\section{Disclosure statement}

The authors report no potential conflict of interest.

\section{References}

Cox G.F.N. \& Weeks W.F. 1983. Equations for determining the gas and brine volumes in sea-ice samples. Journal of Glaciology 29, 306-316, doi: 10.3189/S0022143000008364.

Deming J.W. \& Collins R.E. 2017. Sea ice as a habitat for Bacteria, Archaea and viruses. In D.N. Thomas (ed.): Sea ice. Pp. 326-351. Oxford: Blackwell Science.

Dieckmann G.S., Nehrke G., Papadimitriou S., Göttlicher J., Steininger R., Kennedy H., Wolf-Gladrow D. \& Thomas D.N. 2008. Calcium carbonate as ikaite crystals in Antarctic sea ice. Geophysical Research Letters 35, L08501, doi: 10.1029/2008GL033540.

Dieckmann G.S., Nehrke G., Uhlig C., Göttlicher J., Gerland S., Granskog M.A. \& Thomas D.N. 2010. Brief communication: Ikaite $\left(\mathrm{CaCO}_{3} \cdot 6 \mathrm{H}_{2} \mathrm{O}\right)$ discovered in Arctic sea ice. The Cryosphere 4, 227-230, doi: 10.5194/tc-4-227-2010.

Fischer M., Thomas D.N., Krell A., Nehrke G., Göttlicher J., Norman L., Meiners K.M., Riaux-Gobin C. \& Dieckmann G.S. 2013. Quantification of ikaite in Antarctic sea ice. Antarctic Science 25, 421-432, doi: 10.1017/ S0954102012001150.

Fripiat F., Meiners K., Vancoppenolle M., Papadimitriou S., ThomasD., Ackley S., Arrigo K., Carnat G., Cozzi S., Delille B., Dieckmann G., Dunbar R., Fransson A., Kattner G., 
Kennedy H., Lannuzel D., Munro D., NomuraD., Rintala J.-M. \& Tison J.-L. 2017. Macro-nutrient concentrations in Antarctic pack ice: overall patterns and overlooked processes. Elementa-Science of the Anthropocene 5, article no. 13, doi: 10.1525/elementa.217.

Galley R.J., Else B.G.T., Geilfus N.-X., Hare A.A., Babb D., Papakyriakou T., Barber D.G. \& Rysgaard S. 2015. Micrometeorological and thermal control of frost flower growth and decay on young sea ice. Arctic 68, 79-92, doi: 10.14430/ arctic4457.

Geilfus N.-X., Carnat G., Dieckmann G.S., Halden N., Nehrke G., Papakyriakou T., Tison J.-L. \& Delille B. 2013. First estimates of the contribution of $\mathrm{CaCO}_{3}$ precipitation to the release of $\mathrm{CO}_{2}$ to the atmosphere during young sea ice growth. Journal of Geophysical Research-Oceans 118, 244-255, doi: 10.1029/2012JC007980.

Gleitz M., Loeff M.R.v.d., Thomas D.N., Dieckmann G.S. \& Millero F.J. 1995. Comparison of summer and winter inorganic carbon, oxygen and nutrient concentrations in Antarctic sea ice brine. Marine Chemistry 51, 81-91, doi: 10.1016/0304-4203(95)00053-T.

Hare A.A., Wang F., Barber D., Geilfus N.-X., Galley R.J. \& Rysgaard S. 2013. pH evolution in sea ice grown at an outdoor experimental facility. Marine Chemistry 154, 46-54, doi: 10.1016/j.marchem.2013.04.007.

Hu Y.-B., Dieckmann G.S., Wolf-Gladrow D.A. \& Nehrke G.2014. Laboratory study on coprecipitation of phosphate with ikaite in sea ice. Journal of Geophysical Research-Oceans 119, 7007-7015, doi: 10.1002/2014JC010079.

Loose B., Miller L.A., Elliott S. \& Papakyriakou T. 2011 . Sea ice biogeochemistry and material transport across the frozen interface. Oceanography 24, 202-218, doi: 10.5670/ oceanog.2011.72.

Millero F.J. 2006. Chemical oceanography. Boca Raton, FL: CRC Press.

Murphy J. \& Riley J.P. 1962. A modified single solution method for the determination of phosphate in natural waters. Analytica Chimica Acta 27, 31-36, doi: 10.1016/ S0003-2670(00)88444-5.

Nomura D., Nishioka J., Granskog M.A., Krell A., Matoba S., Toyota T., Hattori H. \& Shirasawa K. 2010. Nutrient distributions associated with snow and sediment-laden layers in sea ice of the southern Sea of Okhotsk. Marine Chemistry 119, 1-8, doi: 10.1016/j.marchem.2009.11.005.

Papadimitriou S., Kennedy H., Kennedy P. \& Thomas D.N. 2014. Kinetics of ikaite precipitation and dissolution in seawater-derived brines at sub-zero temperatures to 265 K. Geochimica et Cosmochimica Acta 140, 199-211, doi: 10.1016/j.gca.2014.05.031.

Rysgaard S., Glud R.N., Lennert K., Cooper M., Halden N., Leakey R.J.G., Hawthorne F.C. \& Barber D. 2012. Ikaite crystals in melting sea ice-implications for $\mathrm{pCO}_{2}$ and $\mathrm{pH}$ levels in Arctic surface waters. The Cryosphere 6, 901-908, doi: 10.5194/tc-6-901-2012. 